\title{
C-Reaktif protein/albümin oranının sirotik hastalarda prognostik amaçlı kullanımı
}

\author{
Prognostic utility of C-Reactive protein/albumin ratio in cirrhotic patients
}

\author{
Mustafa KAPLAN ${ }^{1}$, İhsan ATEŞ ${ }^{2}$, Meral AKDOĞAN KAYHAN ${ }^{1}$, Sabite KAÇAR ${ }^{1}$, Muhammet Yener AKPINAR ${ }^{1}$, \\ Volkan GÖKBULUT'1, Orhan COŞKUN¹, Adem AKSOY'1, Ufuk Barış KUZU1 \\ Türkiye Yüksek Ihtisas Eğitim ve Araştırma Hastanesi, 'Gastroenteroloji Kliniği, Ankara \\ Ankara Numune Eğitim ve Araştırma Hastanesi, ${ }^{2} \mid c ̧$ Hastalıkları Kliniği, Ankara
}

\begin{abstract}
Giriş ve Amaç: Bu çalışmada yeni tanı siroz hastalarında tanı anındaki C-reaktif protein-albümin oranının hepatosellüler karsinom, hepatik ensefalopati, mortalite, Child-Pugh ve MELD skorları ile ilişkisini araştırdık. Gereç ve Yöntem: Bu çalışma 2011-2017 yılları arasında Gastroenteroloji ve Hepatoloji polikliniğe başvuran yeni tanı siroz hastalarının hasta kayıtları incelenerek retrospektif olarak yapılmıştır. Çalışmaya alınma anında spontan bakteriyel peritonit, hepatik ensefalopati veya hepatosellüler karsinom tanısı olanlar ve 18 yaşından küçük olanlar çalışmadan dışlanmıştır. Bulgular: Araştırma popülasyonu 78 erkek (\%66.1) ve 40 kadın (\%33.9) hasta olmak üzere 118 kişiden oluştu. Hastaların

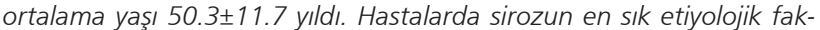
törleri hepatit B (\%37.3), kriptojenik (\%17.8) ve hepatit C (\%11.9) idi. Hastaların ortalama takip süresi 48 aydı. Risk faktörlerinin dahil edildiği çok değişkenli stepwise Cox regresyon modelinde; hepatik ensefalopati gelişmesi (HR:4.21; $p=0.001)$, başlangıç MELD skoru (HR:1.17; $p$ $<0.001)$ ve C-reaktif protein-albümin oranı ( $H R=1.22 ; p<0.001)$ mortalite riskini öngören bağımsız prediktörler olarak saptandı. C-reaktif protein-albümin oranında \% 1'lik artışın 1.22 kat mortalite riskini arttırdığı saptandı. Mortaliteyi öngörmede C-reaktif protein-albümin oranına ait kestirim değeri \%77.1 duyarlılık ve \%95.2 özgüllük ile $\geq 2.4$ olarak saptandı. C-reaktif protein-albümin oranı 2.4 ve üzeri olan hastalarda HES gelişmesi (\%35.5 vs \%10.3; $p=0.004)$, ortalama Child-Pugh skoru $(7.4 \pm 1.9$ vs $6.4 \pm 1.6 ; p<0.001)$, ortalama MELD skoru $(14.2 \pm 3.7$ vs $11.8 \pm 4.1 ; p<0.001)$ ve ölenlerin oranı (\%87.1 vs $\% 9.2 ; p<0.001)$ daha yüksek saptandı. Sonuç: C-reaktif protein-albümin oranı yeni tanı sirotik hastalarda mortalite ve siroz komplikasyonlarını öngörmede kullanılabilecek kolay ölçülebilen ve spesifitesi yüksek bir parametredir.
\end{abstract}

Anahtar kelimeler: CRP, albümin, hepatik ensefalopati, Child-Pugh skoru, MELD skoru

\section{Giriș}

Siroz yüksek mortalite ve morbidite ile seyreden kronik bir hastalıktır (1). Özellikle hepatik ensefalopati (HES) ve hepatosellüler karsinom (HCC) gibi komplikasyonlar nedeniyle mortalite sık görülmektedir $(2,3)$. Hastalık prognozunun belirlenmesi erken karaciğer nakil planı ve agresif tedavi seçimleri açısından önemlidir. Bu amaçla sıklıkla
Background and Aims: In this study, we investigated the relationships between C-reactive protein/albumin ratio and hepatocellular carcinoma, hepatic encephalopathy, mortality, Child-Pugh score and model for endstage liver disease scores in newly diagnosed cirrhotic patients. Materials and Methods: This study was performed retrospectively by examining records of newly diagnosed cirrhotic patients who applied to the Gastroenterology and Hepatology Polyclinic between 2011 and 2017. Patients who were diagnosed with hepatic encephalopathy, hepatocellular carcinoma or spontaneous bacterial peritonitis at admission, and patients younger than 18 years were excluded from the study. Results: The study population was consisted of 118 patients; 78 men (66.1\%) and 40 women (33.9\%). The mean age of the patients was $50.3 \pm 11.7$ years. The most common etiologic factors for cirrhosis were hepatitis $B$ (37.3\%), cryptogenic $(17.8 \%)$ and hepatitis C $(11.9 \%)$. The mean follow-up period for the patients was 48 months. Using the multivariate stepwise Cox regression model in which risk factors were included. hepatic encephalopathy development (HR=4.21; $p=0.001)$, initial model for end-stage liver disease score $(H R=1.17 ; p<0.001)$ and $C$-reactive protein/ albumin ratio ( $H R=1.22 ; p<0.001)$ were found to be independent predictors of mortality risk. A $1 \%$ increase in C-reactive protein/albumin ratio was found to increase the mortality risk 1.22-fold. The cut-off value of C-reactive protein/albumin ratio for predicting mortality was found to be $\geq 2.4$ with $77.1 \%$ sensitivity and $95.2 \%$ specificity. Development of hepatic encephalopathy (35.5\% vs 10.3\%, $p=0.004)$, the mean Child-Pugh score $(7.4 \pm 1.9$ vs $6.4 \pm 1.6, p<0.001)$, the mean model for end-stage liver disease score $(14.2 \pm 3.7$ vs $11.8 \pm 4.1 ; p<0.001)$ and the proportion of dead patients $(87.1 \%$ vs $9.2 \%, p<0.001)$ were significantly higher in patients with a C-reactive protein/albumin ratio of 2.4 or above. Conclusion: C-reactive protein/albumin ratio is an easily measured parameter with a high specificity that can be used in the prediction of mortality and complications in newly diagnosed cirrhotic patients.

Key words: C-reactive protein, albumin, hepatic encephalopathy, Child-Pugh score, model for end-stage liver disease score

Child-Pugh ve son dönem karaciğer hastalığı için model (MELD) skorları kullanılmaktadır (4). Ancak sıklıkla kullanılan bu parametrelerin dışında başvuru anında kolaylıkla ölçülebilen, basit, ucuz, invaziv olmayan ve mortalite gelişim riski hakkında bize fikir verebilecek parametrelere halen intiyaç duyulmaktadır. Siroz ve komplikasyonların 
gelişiminde inflamasyonun önemli bir rolü olduğu düşünülmektedir (5). Bu nedenle sirotik hastalarda değişik inflamasyon markerlarının prognostik amaçı kullanımı araştırılmıştır. C-reaktif protein (CRP) hepatositlerden salınan bir akut faz proteini olup sirotik hastalarda prognostik amaçlı kullanılmaktadır (6). Benzer şekilde bir negatif akut faz reaktanı olan albümin de Child-Pugh skoruna dahil olup sirotik hastalarda hastalığın tanısı ve gidişatı hakkında bilgi vermektedir (7). Bu iki parametrenin birbirine oranı ile ortaya çıkan CRP/Albümin oranı (CAO) ise yeni kullanılmaya başlanan ve hakkında çok fazla çalışma bulunmayan bir parametredir. Daha önce kanser başta olmak üzere değişik hasta gruplarında yapılmış çalışmalarda belirli bir kestirim değerinin üstünde olan hastalarda prognozun daha kötü olduğu ve mortalitenin arttığı gösterilmiştir $(8,9)$. Crohn hastaları ile yapılan bir çalışmada ise CAO'nun hastalık aktivitesi ile ilişkili olduğu gösterilmiştir (10). Ancak literatürde CAO'nun sirotik hastalarda kullanılabilirliğini gösteren bir çalışma bulunmamaktadır. Biz bu çalışmada yeni tanı siroz hastalarında tanı anındaki CAO'nun Child-Pugh ve MELD skorları, HCC, HES ve mortalite ile ilişkisini araştırdık.

\section{GEREÇ ve YÖNTEM}

Bu çalışma 2011-2017 yılları arasında Türkiye Yüksek İhtisas Eğitim ve Araştırma Hastanesi Gastroenteroloji ve Hepatoloji polikliniğe başvuran yeni tanı siroz hastalarının hasta kayıtları incelenerek retrospektif olarak yapılmışır. Çalışmaya alınma anında spontan bakteriyel peritonit, HES veya HCC tanısı olanlar ve 18 yaşından küçük olanlar çalışmadan dışlanmışır.

Hastaların ilk başvuru anındaki kan sonuçları, Child-Pugh ve MELD skorları dosyalarından elde edilmiştir. Hastalar 6 aylık aralıklarla siroz komplikasyonları açısından taranmış ve hastaların her gelişinde Child-Pugh ve MELD skorları hesaplanarak dosyasına kaydedilmiştir. Hastalarda mortalite gelişip gelişmediği bilgisine ulusal veri tabanı incelenerek ulaşılmıştır. Hastaların ilk başvurudan son kontrol zamanına veya mortalite gelişen hastalarda mor- taliteye kadar geçen süre takip süresi olarak alınmıştır. CRP için 0-5 mg/L, albümin için ise 3.5-5.5 g/dL değerleri referans olarak alınmıştır. CAO, CRP değerinin albümine bölünmesi ile elde edilmiştir.

İstatistiksel değerlendirme Statistical Package for Social Sciences (SPSS) for Windows 20 (IBM SPSS Inc., Chicago, IL) programı kullanılarak yapıldı. Verilerin normal dağılımı Kolmogorov-Smirnov testi ile değerlendirildi. Sayısal değişkenlerden normal dağıım sergileyenler ortalama \pm standart sapma olarak, normal dağılım sergilemeyenler ortanca (min-max) olarak gösterildi. CAO ile sayısal değişkenler arasındaki ilişki Spearman korelasyon analizi ile incelendi. Mortaliteyi etkileyen bağımsız prediktörlerin tespitinde stepwise Cox regresyon analizi kullanıldı. Bağımsız prediktörlerin mortalite üzerindeki tanısal performansı ROC Curve analizi ile incelendi. CAO'ya ait kestirim değeri ROC Curve analizi Youden index metodu ile belirlendi. Sağ kaIım grafikleri Kaplan Meier analizi ile gösterildi. İstatistiksel analizlerde $p<0.05$ değeri anlamlı olarak kabul edildi.

\section{BULGULAR}

Araştırma popülasyonu 78 erkek (\%66.1) ve 40 kadın (\%33.9) hasta olmak üzere 118 kişiden oluştu. Hastaların ortalama yaşı $50.3 \pm 11.7$ yıldı. Hastalarda sirozun en sık etiyolojik faktörleri hepatit B (\%37.3), kriptojenik (\%17.8) ve hepatit C (\%11.9) idi (Şekil 1). Hastaların takip süresi 12-84 ay aralığında olup ortancası 48 aydı. Takipte hastaların \%6.8'inde (n:8) HCC, \%29.7'sinde (n:20) HES saptandı. Hastaların \%29.7'inde (n:35) takip süresince mortalite gelişti.

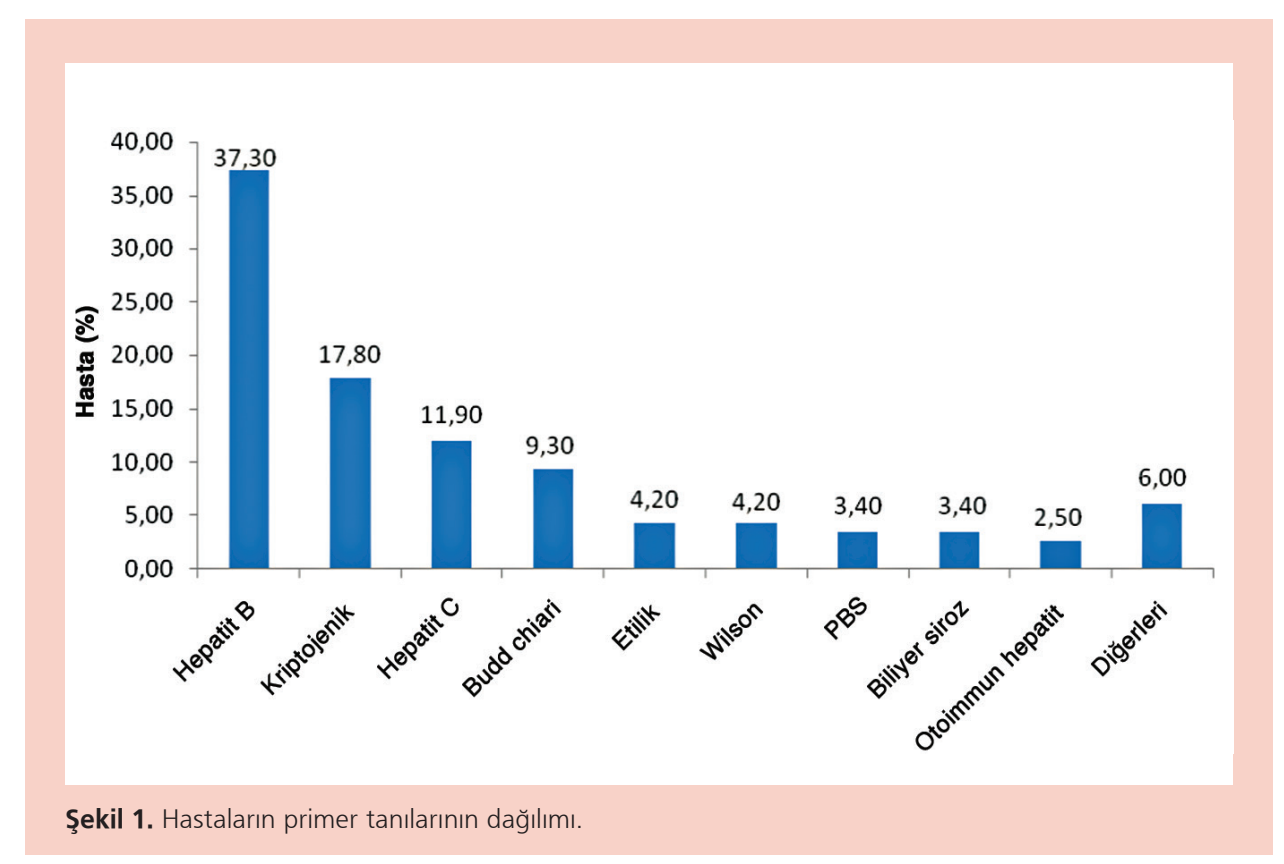




\begin{tabular}{|c|c|c|c|c|c|}
\hline \multirow[b]{2}{*}{ Değişkenler } & \multicolumn{2}{|c|}{ Mortalite } & \multirow[b]{2}{*}{ HR } & \multirow[b]{2}{*}{$95 \% \mathrm{Cl}$} & \multirow[b]{2}{*}{$\mathbf{P}$} \\
\hline & Yok $(n=83)$ & $\operatorname{Var}(n=35)$ & & & \\
\hline Yaş & $48.0 \pm 11.6$ & $55.65 \pm 10.14$ & 1.07 & $1.03-1.11$ & $0.001 *$ \\
\hline \multicolumn{6}{|l|}{ Cins } \\
\hline Kadın & $30(36.1)$ & $10(28.6)$ & Ref. & & \\
\hline Erkek & $53(63.9)$ & $25(71.4)$ & 1.26 & $0.61-2.63$ & 0.532 \\
\hline \multicolumn{6}{|l|}{ HCC gelişimi } \\
\hline Yok & $79(95.2)$ & $31(88.6)$ & Ref. & & \\
\hline Var & $4(4.8)$ & $4(11.4)$ & 3.49 & $1.20-10.21$ & $0.022^{*}$ \\
\hline \multicolumn{6}{|l|}{ HES gelişimi } \\
\hline Yok & $78(94.0)$ & $20(57.1)$ & Ref. & & \\
\hline Var & $5(6.0)$ & $15(42.9)$ & 5.09 & $2.56-10.14$ & $<0.001 *$ \\
\hline Illk Child-Pugh skoru & $6.2 \pm 1.2$ & $7.8 \pm 2.19$ & 1.40 & $1.19-1.63$ & $<0.001^{*}$ \\
\hline Illk MELD skoru & $11.1 \pm 3.3$ & $15.5 \pm 4.0$ & 1.16 & $1.09-1.24$ & $<0.001 *$ \\
\hline Hemoglobin (g/dL) & $12.8 \pm 2.1$ & $11.7 \pm 2.1$ & 0.83 & $0.71-0.95$ & $0.009 *$ \\
\hline WBC $\left(\times 10^{\wedge} 3 / \mathrm{uL}\right)$ & $4700(1000-10000)$ & $4500(1000-8300)$ & 0.99 & $0.98-1.02$ & 0.551 \\
\hline Trombosit (x10^3/uL) & $109(12-426)$ & $75(18-205)$ & 0.97 & $0.95-0.99$ & $0.023^{*}$ \\
\hline INR & $1.5 \pm 0.4$ & $1.5 \pm 0.3$ & 1.06 & $0.64-1.76$ & 0.815 \\
\hline Kreatinin (mg/dl) & $0.7(0.3-2.5)$ & $0.8(0.4-1.9)$ & 1.45 & $0.54-3.92$ & 0.462 \\
\hline CRP (mg/L) & $2.1(0.1-12.0)$ & $18.5(2.5-49.0)$ & 1.07 & $1.04-1.10$ & $<0.001^{*}$ \\
\hline Albümin (g/dL) & $3.9 \pm 0.6$ & $3.4 \pm 0.7$ & 0.46 & $0.30-0.71$ & $<0.001^{*}$ \\
\hline CRP/Albümin oranı & $0.6(0.02-3.8)$ & $4.5(0.6-37.3)$ & 1.21 & $0.15-1.27$ & $<0.001 *$ \\
\hline
\end{tabular}

${ }^{*} p<0.05$ istatistiksel anlamllık göstermektedir. HCC: Hepatosellüler karsinom, HES: Hepatik ensefalopati, MELD: Model for End-Stage Liver Disease, WBC: Beyaz küre sayISI, CRP: C-reaktif protein, INR: International Normalized Ratio, Ref: Referans, HR: Hazard ratio, Cl: Confidence interval.

Mortalite açısından olası risk faktörleri Tablo 1'de gösterilmiş̧ir. Tablo 1'de anlamlı bulunan olası risk faktörlerinin dahil edildiği çok değişkenli stepwise Cox regresyon modelinde; HES gelişimi (HR:4.21; $p=0.001)$, MELD skoru (HR:1.17; $p<0.001)$ ve CAO (HR=1.22; $p<0.001)$ mortalite riskini öngören bağımsız prediktörler olarak saptandı (Tablo 2). HES gelişen hastalarda gelişmeyenlere kıyasla mortalite riski 4.21 kat artmıştı. MELD skorunda 1 skorluk artışın mortalite riskini 1.17 kat artırıdığı saptandı. CRP/ Albümin oranında \% $1^{\prime}$ lik artışın mortalite riskini 1.22 kat arttırdığı saptandı.

Mortaliteyi öngören bağımsız prediktörler ile albümin ve CRP düzeylerinin tanısal performansı ROC Curve analizi ile incelendi. Buna göre CRP/Albümin oranı diğer değişkenlerden anlamlı olarak yüksek AUC değerine sahipti (Şekil 2). Mortaliteyi öngörmede CRP/Albümin oranına ait kestirim değeri \%77.1 duyarlılık ve \%95.2 özgüllük ile 22.4 olarak saptandı (Şekil 3).
CAO 2.4 ve üzeri olan hastalarda ortalama yaş daha yüksekti $(54.7 \pm 10.7$ vs $48.7 \pm 11.7 ; p=0.001)$. CAO 2.4 ve üzeri olan hastalarda HES gelişmesi (\%35.5 vs $\% 10.3$; $\mathrm{p}=0.004$ ), ortalama Child-Pugh skoru (7.4 \pm 1.9 vs $6.4 \pm 1.6$; $\mathrm{p}<0.001$ ) ve ortalama MELD skoru (14.2 \pm 3.7 vs $11.8 \pm 4.1$; $\mathrm{p}<0.001)$ daha yüksek saptandı. CAO 2.4 ve üzeri olan hastalarda ortalama hemoglobin düzeyi $(11.9 \pm 2.2$ vs

Tablo 2. Mortaliteyi öngören bağımsız prediktörler

\begin{tabular}{llcc}
\hline Değişkenler & HR & $\mathbf{9 5 \%} \mathbf{C l}$ & $\mathbf{p}$ \\
\hline HES gelişimi & & & \\
\hline Yok & Ref. & & \\
\hline Var & 4.21 & $1.85-9.59$ & $0.001^{*}$ \\
\hline Illk MELD skoru & 1.17 & $1.07-1.26$ & $<0.001^{*}$ \\
\hline CRP/Albümin oranı & 1.22 & $1.14-1.28$ & $<0.001^{*}$ \\
\hline
\end{tabular}

${ }^{*} p<0.05$ istatistiksel anlamllık göstermektedir. HES: Hepatik ensefalopati, CRP: C-reaktif protein, MELD: Model for End-Stage Liver Disease, Ref: Referans, HR: Hazard ratio, Cl: Confidence interval. 


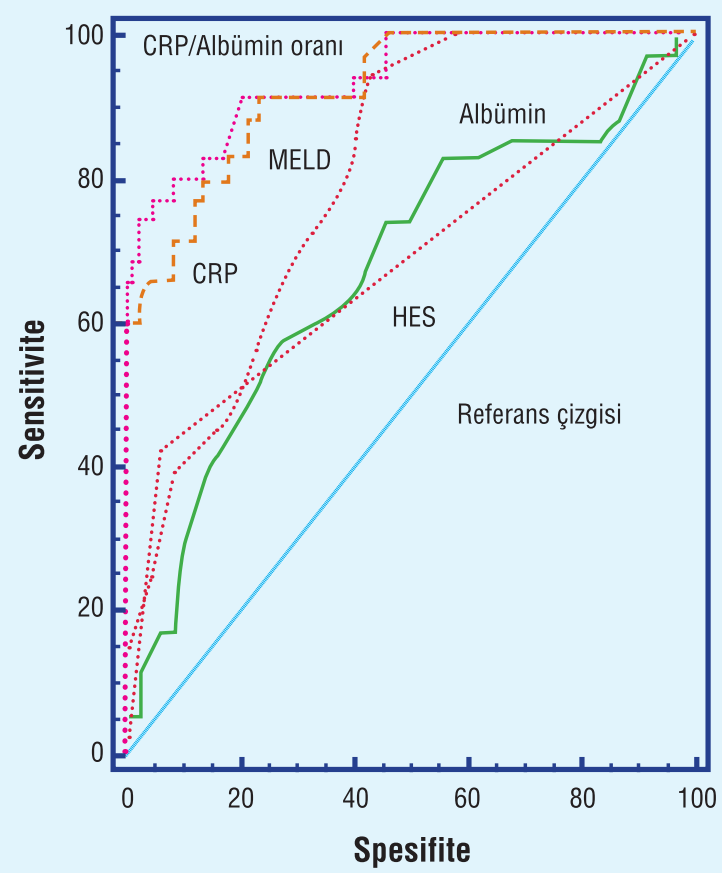

\begin{tabular}{|c|c|}
\hline \multicolumn{2}{|l|}{ Albümin CRP } \\
\hline Alanlar arası fark & 0.244 \\
\hline Standart sapma & 0.064 \\
\hline$p$ & $<0.001$ \\
\hline \multicolumn{2}{|c|}{ Albümin CRP/Albümin oranı } \\
\hline Alanlar arası fark & 0.259 \\
\hline Standart sapma & 0.060 \\
\hline$p$ & $<0.001$ \\
\hline \multicolumn{2}{|l|}{ Albümin HES } \\
\hline Alanlar arası fark & 0.006 \\
\hline Standart sapma & 0.068 \\
\hline$p$ & 0.929 \\
\hline \multicolumn{2}{|c|}{ Albümin MELD skoru } \\
\hline Alanlar arası fark & 0.146 \\
\hline Standart sapma & 0.064 \\
\hline $\mathrm{p}$ & 0.050 \\
\hline \multicolumn{2}{|c|}{ CRP CRP/Albümin oranı } \\
\hline Alanlar arası fark & 0.015 \\
\hline Standart sapma & 0.007 \\
\hline$p$ & 0.040 \\
\hline \multicolumn{2}{|l|}{ CRP HES } \\
\hline Alanlar arası fark & 0.238 \\
\hline Standart sapma & 0.053 \\
\hline$p$ & 0.001 \\
\hline \multicolumn{2}{|l|}{ CRP MELD skoru } \\
\hline Alanlar arası fark & 0.098 \\
\hline Standart sapma & 0.052 \\
\hline$p$ & 0.034 \\
\hline \multicolumn{2}{|c|}{ CRP/Albümin oranı HES } \\
\hline Alanlar arası fark & 0.253 \\
\hline Standart sapma & 0.050 \\
\hline $\mathrm{p}$ & 0.001 \\
\hline \multicolumn{2}{|c|}{ CRP/Albümin oranı MELD skoru } \\
\hline Alanlar arası fark & 0.113 \\
\hline Standart sapma & 0.051 \\
\hline $\mathrm{p}$ & 0.019 \\
\hline \multicolumn{2}{|l|}{ HES MELD skoru } \\
\hline Alanlar arası fark & 0.140 \\
\hline Standart sapma & 0.061 \\
\hline$p$ & 0.041 \\
\hline Delog et al. 1988 & \\
\hline
\end{tabular}

Şekil 2. Mortalite açısından bağımsız prediktörlerin tanısal performans değerlendirmesi.

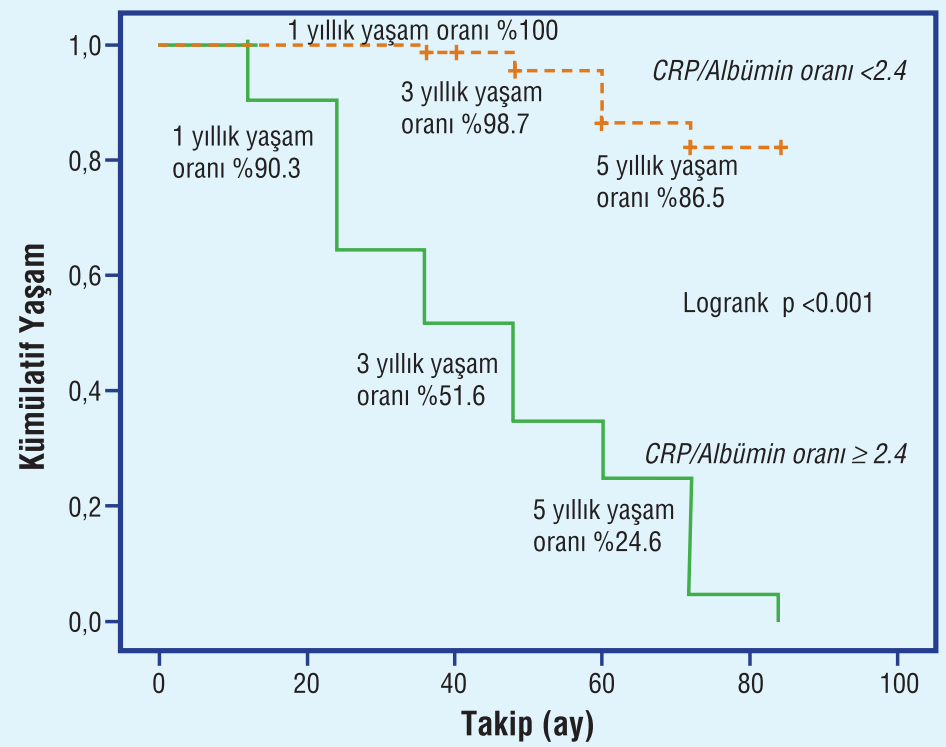

$12.7 \pm 2.2 ; p=0.011)$ ve ortalama albümin düzeyi $(3.3 \pm 0.8 \mathrm{vs}$ $3.8 \pm 0.6 ; p=0.002)$ düşük saptandı. CAO 2.4 ve üzeri olan hastalarda ortanca kreatinin düzeyi (0.9 vs $0.7 ; p=0.044$ ) ve ortanca CRP (20.5 vs 2.4; $\mathrm{p}$ $<0.001)$ daha yüksek saptandı. CAO 2.4 ve üzeri olan hastalarda ölenlerin oranı daha yüksek (\%87.1 vs $\% 9.2 ; p<0.001$ ) ve ortanca izlem süresi daha düşük (36 vs 48; $p=0.007$ ) saptandı (Tablo 3).

Şekil 3. CRP Albümin oranına ait kestirim değerinin sağkalım grafiği (2) 
Tablo 3. CRP/Albümin oranına ait kestirim değerine göre demografik ve klinik bulguların dağılımı

\begin{tabular}{|c|c|c|c|}
\hline \multicolumn{4}{|c|}{ CRP/Albümin oranı } \\
\hline Değişkenler & $<2.4$ & $\geq 2.4$ & p \\
\hline Yaş & $48.7 \pm 11.7$ & $54.7 \pm 10.7$ & $0.001 *$ \\
\hline \multicolumn{4}{|l|}{ Cinsiyet } \\
\hline Kadın & $32(36.8)$ & $8(25.8)$ & 0.377 \\
\hline Erkek & $55(63.2)$ & $23(74.2)$ & \\
\hline \multicolumn{4}{|l|}{ HCC gelişimi } \\
\hline Yok & $83(95.4)$ & $27(87.1)$ & 0.204 \\
\hline Var & $4(4.6)$ & $4(12.9)$ & \\
\hline \multicolumn{4}{|l|}{ HES gelişimi } \\
\hline Yok & $78(89.7)$ & $20(64.5)$ & $0.004^{\star}$ \\
\hline Var & $9(10.3)$ & $11(35.5)$ & \\
\hline Illk Child-Pugh skoru & $6.4 \pm 1.6$ & $7.4 \pm 1.9$ & $<0.001$ * \\
\hline Illk MELD skoru & $11.8 \pm 4.1$ & $14.2 \pm 3.7$ & $<0.001^{*}$ \\
\hline Hemoglobin (g/dL) & $12.7 \pm 2.2$ & $11.9 \pm 2.2$ & $0.011^{*}$ \\
\hline WBC (x10^3/uL) & $4700(1000-10000)$ & $5000(1000-8300)$ & 0.871 \\
\hline Trombosit $\left(\times 10^{\wedge} 3 / \mathrm{uL}\right)$ & $98(12-426)$ & $75(30-205)$ & 0.124 \\
\hline INR & $1.5 \pm 0.6$ & $1.5 \pm 0.3$ & 0.574 \\
\hline Kreatinin (mg/dl) & $0.7(0.3-2.5)$ & $0.9(0.5-1.9)$ & $0.044^{\star}$ \\
\hline $\operatorname{CRP}(\mathrm{mg} / \mathrm{L})$ & $2.4(0.1-10.7)$ & $20.5(7.2-49)$ & $<0.001^{*}$ \\
\hline Albümin ( $\mathrm{g} / \mathrm{dL})$ & $3.8 \pm 0.6$ & $3.3 \pm 0.8$ & $0.002^{*}$ \\
\hline \multicolumn{4}{|l|}{ Sağ kalım } \\
\hline Yaşayan & $79(90.8)$ & $4(12.9)$ & $<0.001^{*}$ \\
\hline Ölen & $8(9.2)$ & $27(87.1)$ & \\
\hline İzlem süresi & $48(12-84)$ & $36(12-84)$ & $0.007^{*}$ \\
\hline
\end{tabular}

\section{TARTIŞMA}

Bu çalışmada CRP/Albümin oranının yeni tanı sirotik hastalarda mortaliteyi öngörmede bağımsız bir prediktör olduğu, CAO'nun 2.4 ve üzeri olduğu hastalarda ortalama Child-Pugh ve MELD skorunun daha yüksek bulunduğu ve bu hastalarda mortalite ve HES gelişmesinin daha fazla olduğu gösterilmiştir. Bu çalışma sirotik hastalarda CAO'nun prognostik önemini araştıran ilk çalışmadır.

Çalışmamızda sirotik hastalarda mortalite için birçok risk faktörü belirlenmiştir. Illerlemiş yaş, HCC ve HES gelişmesi, artmış Child-Pugh ve MELD skorları, düşük albümin, trombosit ve hemoglobin düzeyleri ve artmış CRP ve CAO bunların başlıcalarıdır. Tüm bu risk faktörlerinin dahil edildiği regresyon analizinde HES gelişmesi, MELD skoru ve CAO mortalite riskini öngören bağımsız prediktörler olarak saptanmıştır. Stewart ve ark. yaptığı çalışmada hastalarda HES gelişmesi mortaliteyi öngörmede prognostik skorlar ile tek başına ve kombine şekilde kıyaslanmış ve HES gelişmesinin mortaliteyi öngörmede efektif bir yöntem olduğu bulunmuştur (11). Yine benzer şekilde Wong ve ark. yaptığı çalışmada nakil bekleyen hastalarda evre 3 ve 4 HES varlığının MELD skorundan bağımsız olarak mortalite ile doğrudan ilişkili olduğu görülmüştür (12). Bizim çalışmamızda da HES gelişmesinin mortaliteyi 4 kat arttırdığı bulunmuştur. MELD skoru da bilindiği gibi esas olarak nakil bekleyen hastalarda mortalite riskini öngörmek için kullanılmaktadır (13). Bizim çalışmamız bu bulguları desteklerken bu parametrelere benzer şekilde CAO'nun da mortalite için bağımsız bir risk faktörü olduğu bulunmuştur. Ancak bu üç risk faktörünün kıyaslandığı ROC Curve analizinde CAO en yüksek AUC değerine sahip bulunmuştur. HES tanısının ayrıntılı muayene ve laboratuvar testleri gerektirmesi, MELD skorunun ise sirozda sık görülen kas kaybı ve uluslararası normalleştirilmiş oran (INR) ölçümündeki uyumsuzluklar nedeniyle bazen 
yanlış hesaplanması nedeniyle rutin laboratuvar testlerinden kolaylıkla ölçülebilen, basit, objektif, güvenilir ve ucuz bir parametre olan CAO'nun bu parametreler yerine kullanılabileceğini düşünüyoruz. Nitekim çalışmamızda CAO'nun ROC Curve analizinde en yüksek tanısal ayrıma sahip olması da bizi desteklemektedir.

Daha önceki yapılan çalışmalarda CAO'nun özellikle malign hastalıklarda prognoz ve mortalite belirteci olarak etkinliği çalışılmıştır (14-16). CAO ile ilgili yapılan çalışmaların çoğu kanser hastalarında yapılmış olup siroz gibi mortalitesi yüksek kronik hastalıklarda çok fazla çalışılmamıştır. Bizim çalışmamızda yukarıdaki çalışmalara benzer olarak CAO mortaliteyi öngörmede bağımsız bir prediktör olarak bulunmuştur. Yukarıdaki çalışmalarda CAO, kanser hastalarında Glasgow Prognostik Score gibi sağ kalım beklentisi için standart kullanılan skorlar ile kıyaslanmış ve onlara üstün bulunmuştur. Bizim çalışmamızda da sirotik hastalarda en sık kullanılan Child-Pugh ve MELD skorları ile CAO kıyaslanmış ve CAO en yüksek AUC ve tanısal değere sahip bulunmuştur.

CAO sadece mortalite belirteci olarak değil agresif tedavi uygulanacak hastaların seçiminde de efektif bir parametredir. Daha önce inflamatuvar barsak hastalıkları ile yapılmış çalışmalarda CAO'nun hastalık aktivitesinin belirlenmesi ve erken steroid tedavisinin kimlere verileceği konusunda yararlı bir belirteç olduğu gösterilmiştir $(10,17)$. Bizim çalışmamızda da sirotik hastalarda hastalık başlangıcında bakılan CAO'nun hastalığın seyri ve şiddeti hakkında fikir verebileceğini düşünüyoruz. Nitekim sirotik hastalarda hangi hastanın daha erken nakil ihtiyacı olduğunu öngörmede sıklıkla kullanılan MELD skoru ile CAO'nun ilişkili bulunması bizim tezimizi desteklemektedir.

Daha önce yapılmış çalışmalarda mortaliteyi öngörmede farklı kestirim değerleri bulunmuştur. Kestirim değerleri Wei ve ark.'nın yaptığı çalışmada 0.095 (14), Xu ve ark.'nın yaptığı çalışmada 0.5 (15), Sun ve ark.'nın yaptığı çalışmada ise 0.189 saptanmıştır (16). Bizim çalışmamızda ise kestirim değeri 2.4 olarak bulunmuştur. Kestirim değerlerinin farklı çıkmasının sebebi ise çalışmalarda kullanılan birimlerin farklı olmasıdır. Yukarıdaki çalışmalarda albümin için referans değeri $\mathrm{g} / \mathrm{L}$, bizim çalışmamızda ise $\mathrm{g} / \mathrm{dL}$ olarak alınmıştır. Bizım çalışmamızda referans değeri $\mathrm{g} / \mathrm{L}$ alındığında kestirim değerimiz 0.24 olarak çıkmakta ve Peng ve ark.'nın çalışmasındaki kestirim değerine yakın bulunmaktadır. Çalışmamızda bulunan 2.4 kestirim değerinin yüksek bir spesifitesinin olması nedeniyle mortaliteyi öngörmede etkin bir şekilde kullanılabileceğini düşünüyoruz.
Daha önce yapılan çalışmalarda tek başına CRP mortaliteyi öngörmede MELD skoruna üstün bulunmuştur (6). Ayrıca albümin de tek başına hem sirozda hem de kanser hastalarında sağ kalımın azalması ile ilişkilidir (18). Bu parametreler tek başına iyi bir mortalite belirteci iken bu parametrelerin kombinasyonundan oluşan CAO'nun daha yüksek AUC değerine sahip olması nedeniyle mortaliteyi öngörmede daha efektif olduğunu düşünüyoruz. CAO'nun CRP ve albüminin basit bir oranından ziyade CRP ve albüminin geniş kapsamlı ve efektif bir hali olduğunu belirtmek gerekir. Bu nedenle de CAO'nun sirotik hastalarda mortaliteyi öngörmede daha dinamik bir yapıya sahip olması nedeniyle bu parametrelerin tek başına kullanımından daha güvenilir ve doğru sonuçlar elde edileceğini iddia ediyoruz.

Çalışmamızda CAO'nun diğer klinik parametreler ile de ilişkisi araştırılmış ve kreatitin yüksekliği ve hemoglobin düşüklüğü ile ilişkili bulunmuştur. Bu bulgular CAO yüksek olan hastalarda görülen yüksek mortalitenin böbrek yetmezliği ve herhangi bir sebepli anemi gibi faktörlerden etkilenmiş olabileceğini düşündürmektedir. CAO yüksek olan hastalarda takip süresinin kısa olmasının nedeni ise bu hastalarda mortalitenin diğer hasta grubuna göre fazla görülmesidir.

Çalışmamızın güçlü yanları takip süremizin uzun, hasta sayımızın yeterli ve CAO'nun non-invaziv, kolay ölçülebilen, basit ve klinikte sıklıkla kullanılan parametrelerden hesap edilebiliyor olmasıdır. Çalışmamızın en önemli kısıtlılı̆ı retrospektif ve tek merkezde yapılmış olmasıdır. Ancak merkezimizin 3. basamak bir sevk merkezi olması nedeniyle yeterli sayıda ve çeşitte hasta profiline sahip olduğumuzu düşünüyoruz. Bir diğer önemli kısıtlık ise CAO'nun sirozun diğer önemli komplikasyonlarından olan varis kanaması ve hepatorenal sendrom gibi komplikasyonlar ile kıyaslanmamış olmasıdır. Özellikle CRP değerinin enfeksiyonlardan etkilenmesi ise önemli bir sorundur ancak özellikle çalışmaya başlangıcında spontan bakteriyel peritonit gibi primer enfeksiyona sahip hastaların çalışmaya alınmaması nedeniyle bu çalışmada çok fazla etkisi olduğunu düşünmüyoruz.

Sonuç olarak CAO basit, ucuz ve rutin kullanımda olan klinik testlerden kolaylıkla ölçülebilen bir parametredir ve yeni tanı sirotik hastalarda mortalite, HES ve prognostik skorlarla ilişkilidir. CAO'nun klinik kullanımı ile ilgili daha ayrıntılı ve geniş kapsamlı prospektif klinik çalışmalar yapılmasına ihtiyaç duyulmaktadır. 


\section{KAYNAKLAR}

1. Altamirano-Barrera A, Barranco-Fragoso B, Méndez-Sánchez N. Management strategies for liver fibrosis. Ann Hepatol 2017;16:48-56.

2. Djiambou-Nganjeu $\mathrm{H}$. Hepatic encephalopathy in liver cirrhosis. J Transl Int Med 2017;5:64-7.

3. Chedid MF, Kruel CRP, Pinto MA, et al. Hepatocellular carcinoma: diagnosis and operative management. Arq Bras Cir Dig 2017;30:272-8.

4. Peng Y, Qi X, Guo X. Child-Pugh versus MELD score for the assessment of prognosis in liver cirrhosis: A systematic review and meta-analysis of observational studies. Medicine (Baltimore). 2016;95:e2877.

5. Koyama Y, Brenner DA. Liver inflammation and fibrosis. J Clin Invest 2017;127:55-64.

6. Cervoni JP, Amorós À, Bañares R, et al. Prognostic value of C-reactive protein in cirrhosis: external validation from the CANONIC cohort. Eur J Gastroenterol Hepatol 2016;28:1028-34.

7. Brown RS Jr, Kumar KS, Russo MW, et al. Model for end-stage liver disease and Child-Turcotte-Pugh score as predictors of pretransplantation disease severity, posttransplantation outcome, and resource utilization in United Network for Organ Sharing status 2A patients. Liver Transpl 2002;8:278-84.

8. Yu ST, Zhou Z, Cai Q, et al. Prognostic value of the C-reactive protein/albumin ratio in patients with laryngeal squamous cell carcinoma. Onco Targets Ther 2017;10:879-84.

9. Liu Z, Jin K, Guo M, et al. Prognostic value of the CRP/Alb ratio, a novel inflammation-based score in pancreatic cancer. Ann Surg Oncol 2017;24:561-8.

10. Qin G, Tu J, Liu L, et al. Serum albumin and C-reactive protein/Albumin ratio are useful biomarkers of Crohn's disease activity. Med Sci Monit 2016;22:4393-400.
11. Stewart CA, Malinchoc M, Kim WR, Kamath PS. Hepatic encephalopathy as a predictor of survival in patients with end-stage liver disease. Liver Transpl 2007;13:1366-71.

12. Wong RJ, Gish RG, Ahmed A. Hepatic encephalopathy is associated with significantly increased mortality among patients awaiting liver transplantation. Liver Transpl 2014;20:1454-61.

13. Kamath PS, Wiesner $\mathrm{RH}$, Malinchoc $\mathrm{M}$, et al. A model to predict survival in patients with end-stage liver disease. Hepatology 2001;33:464-70.

14. Wei XL, Wang FH, Zhang, et al. A novel inflammation-based prognostic score in esophageal squamous cell carcinoma: the C-reactive protein/albumin ratio. BMC Cancer 2015;15:350.

15. $\mathrm{Xu} \mathrm{XL}, \mathrm{Yu} \mathrm{HQ}$, Hu W, Song Q, Mao WM. A novel inflammation-based prognostic score, the C-reactive protein/Albumin ratio predicts the prognosis of patients with operable esophageal squamous cell carcinoma. PLoS One 2015;10:e0138657.

16. Sun $P$, Chen $C$, Xia $Y$, et al. The ratio of C-reactive protein/Albumin is a novel inflammatory predictor of overall survival in cisplatin-based treated patients with metastatic nasopharyngeal carcinoma. Dis Markers 2017;2017:6570808.

17. Gibson DJ, Hartery K, Doherty J, et al. CRP/Albumin ratio: An early predictor of steroid responsiveness in acute severe ulcerative colitis. J Clin Gastroenterol 2017 Jul 21.

18. Asher V, Lee J, Bali A. Preoperative serum albumin is an independent prognostic predictor of survival in ovarian cancer. Med Oncol 2012;29:2005-9. 